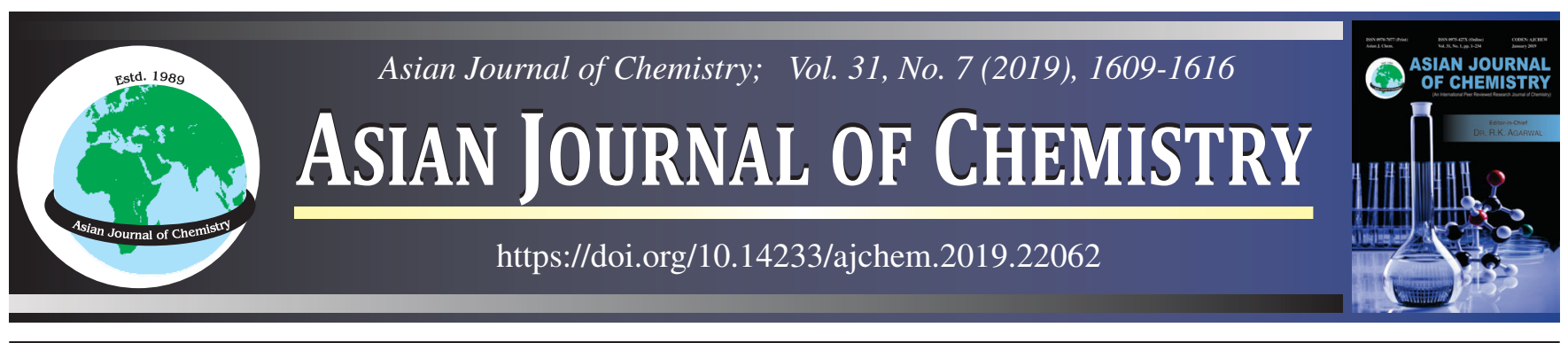

\title{
Synthesis of New 2-Amino-6-(4-hydroxy-2-oxo-chromen-3-yl)-4-aryl Nicotine Nitrile in Eco-Friendly Media and their Antimicrobials and DPPH Radical Scavenging Activities
}

\author{
Aziza Mnasri ${ }^{1}$, A. Chakchouk-MtibaA ${ }^{2}$, Abdullah Sulaiman Al-Ayed ${ }^{3}$, \\ Mosbah Jemmali ${ }^{3}$, L. Mellouli $I^{2}$, Hallouma Bilel ${ }^{1,4}$ and Naceur Hamdi ${ }^{1,3, *}$
}

${ }^{1}$ Research Laboratory of Environmental Sciences and Technologies (LR16ES09), Higher Institute of Environmental Sciences and Technology, University of Carthage, Hammam-Lif, Tunisia

${ }^{2}$ Laboratory of Microorganisms and Biomolecules of the Center of Biotechnology of Sfax-Tunisia. Road of Sidi Mansour, Km 6 B.P. 1117 , 3018 Sfax, Tunisia

${ }^{3}$ Department of Chemistry, College of Science and Arts, Qassim University, Al-Rass, Kingdom of Saudi Arabia

${ }^{4}$ Department of Chemistry, College of Science, Jouf University, P.O. Box: 2014, Sakaka, Saudi Arabia

*Corresponding author: Fax: +966 63339351; Tel: +966 556394839; E-mail: naceur.hamdi@isste.rnu.tn

\begin{abstract}
A simple, green, efficient and economical procedure for the synthesis of, 2-amino-6-(4-hydroxy-2-oxo-chromen-3-yl)-4-(aryl) nicotine nitrile (4a-g) by two routes carried in same conditions, have been reported. The new compounds $\mathbf{4 a - g}$ were characterized by ${ }^{1} \mathrm{H} \mathrm{NMR}$, ${ }^{13} \mathrm{C}$ NMR, FT-IR and elemental analysis. The synthesized compounds were screened for their antibacterial activities against Gram-positive bacterial strains (Micrococcus luteus LB14110, Staphylococcus aureus ATCC 6538, Listeria monocytogenes ATCC 19117), Gram-negative bacteria (Escherichia coli, Salmonella typhimurium ATCC 14028 and Pseudomonas aeruginosa). The coumarin derivative 4a and 3acetyl-4-hydroxycouamrin (1) were the most active against two bacteria Staphylococcus aureus ATCC 6538 and Candida albicans respectively. The best minimum inhibitory concentration values were obtained for the compound $\mathbf{4 a}$ against Candida albicans (0.0195 g/ $\mathrm{cm}^{3}$ ). In addition, compounds 4a-g were investigated for their antioxidant activities by DPPH (2,2-diphenyl-1-picrylhydrazyl) in which most of them displayed significant antioxidant activities.
\end{abstract}

Keywords: 3-Acetyl-4-hydroxycoumarin, Multicomponent reactions, Biological activities.

\section{INTRODUCTION}

Coumarins and their derivatives have attracted considerable attention due to their extensive biological activities, including antioxidant and anti-inflammatory [1], antiviral [2,3], anticoagulant [4], antimicrobial [5,6] and anticancer properties $[7,8]$. On the other hand, multicomponent reactions have been successfully employed to generate highly diverse combinatorial libraries for high-throughput screening of biological and pharmacological activities $[9,10]$. This type of reaction becomes increasingly important in organic and medicinal chemistry because it allows to obtain highly sophisticated polyfunctional molecules through simple one-pot procedures [11,12]. Multicomponent reaction protocol with environmentally benign solvents and catalytic systems is one of the most suitable strategies, which meets the requirements of green aspects of chemistry for developing libraries of medicinal scaffolds. In addition, water has emerged as a versatile solvent for organic reactions in the last two decades since it is readily available, inexpensive, environmentally benign, neutral and a natural solvent $[13,14]$. For these reasons, water has been used for multicomponent reaction (MCRs) as well $[15,16]$. Multicomponent reaction in water are of outstanding value in organic synthesis and green chemistry. In the course of our continuing interest on the synthesis of condensed coumarin derivatives with antiinflammatory and antioxidant activities $[17,18]$ we have extended our research to the synthesis, characterization and biological evaluation of new bioactive coumarins derivatives 4a-g via an environmentally friendly reaction condition. Here, we report: (i) the synthesis of novel 2-amino-6-(4-hydroxy-2oxo-chromen-3-yl)-4-(aryl) nicotine nitrile (4a-g) which were obtained by two different routes in the pursuit of finding bio-

This is an open access journal, and articles are distributed under the terms of the Creative Commons Attribution-NonCommercial-ShareAlike 4.0 (CC BY-NC-SA 4.0) International License which allows readers to freely read, download, copy, distribute, print, search, or link to the full texts of its articles and to use them for any other lawful non-commercial purpose as long as the original source is duly acknowledged. 
logically active compounds that can be further investigated for their antimicrobial and antioxidant activities, (ii) the structures of these new coumarins derivatives were characterized by spectroscopic methods $\left({ }^{1} \mathrm{H}\right.$ and ${ }^{13} \mathrm{C}$ NMR, FT-IR and elemental analysis, (iii). The obtained compounds were screened for their ability to inhibit the growth of a number of Grampositive and Gram-negative and fungi strains, which have not been studied in the past. In addition, their antioxidant activities were evaluated.

\section{EXPERIMENTAL}

All manipulations were performed using standard Schlenck techniques under argon atmosphere. Chemicals were purchased from Sigma Aldrich and used without further purification. All the solvents were purified and dried by MBraun SPS 800 solvent purification system. Column chromatography was performed using silica gel 60 (70-230 mesh). ${ }^{1} \mathrm{H}$ NMR and ${ }^{13} \mathrm{C}$ NMR spectra were recorded at 400 and $100 \mathrm{MHz}$, respectively. Chemical shifts, $\delta$, are reported in ppm relative to the internal standard TMS for both ${ }^{1} \mathrm{H}$ and ${ }^{13} \mathrm{C}$ NMR. The NMR studies were carried out in high-quality $5 \mathrm{~mm}$ NMR tubes. Signals are quoted in parts per million as $\delta$ down-field from tetramethylsilane $(\delta=0.00)$ as an internal standard. IR spectra were recorded on a 398 spectrophotometer (PerkinElmer, King Saud University, Ryadh, Saudi Arabia). Elemental microanalysis was performed on an Elementar Vario El III Carlo Erba 1108 elemental analyzer (Rennes, France) and the values found were within $\pm 0.3 \%$ of the theoretical values. Melting points were determined with Kofler bench at Isste of Borjcedria (Hammam Lif, University of Carthage, Borj Cedria, Tunisia).

General procedure for synthesis of 3-acetyl-4-hydroxycoumarin (1): In a round bottom flask, $3 \mathrm{~g}(18.6 \mathrm{mmol})$ of 4hydroxycoumarin, $16 \mathrm{~mL}$ of acetic acid $(27.9 \mathrm{mmol})$ (solvent and reagent at a time) and $5.6 \mathrm{~mL}(60 \mathrm{mmol})$ of phosphorus oxychloride are added. The reaction was refluxed under continuous stirring for $1 \mathrm{~h}$. Control of the evolution of the reaction by thin layer chromatography (TLC) (eluent: hexane-ethanol 80:20) revealed the formation of a single compound. At the end of the reaction, the product was filtered, recrystallized from ethanol, dried and recovered (Scheme-I).

Yield: $92 \%$; m.p.: $225^{\circ} \mathrm{C}$; FT-IR $\left(\mathrm{KBr}, v_{\max }, \mathrm{cm}^{-1}\right): 3185$ (O-H); 1700 (CO lactone); ${ }^{1} \mathrm{H}$ NMR (400 MHz, DMSO- $d_{6}$ ) ppm $\delta: 2.45$ (s, 3H, CO-CH $\left.{ }_{3}\right) ; 7.15-7.92$ (m, 4H, $\mathrm{H}_{\text {arom }}$ ), 17.72 (s, OH). ${ }^{13} \mathrm{C}$ NMR (100 MHz, DMSO- $d_{6}$ ) in ppm $\delta: 32.36$ $\left(\mathrm{H}_{3} \mathrm{C}-\mathrm{CO}\right) ; 102.32$ (aryl-C=C-OH); 115.91, 122.98, 125.66

$$
{ }_{{ }^{\prime \prime}}^{\mathrm{C}^{\prime \prime}}
$$

3
1
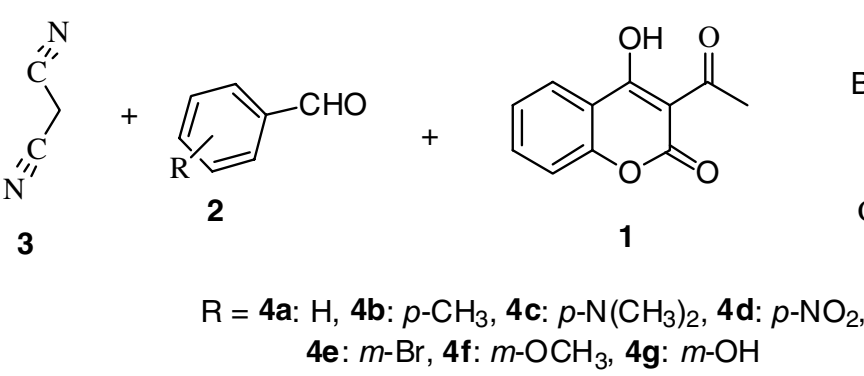

$\left(\mathrm{C}_{\text {arom }}\right) 132.95\left(\mathrm{O}-\mathrm{C}_{\text {arom }}\right) ; 157.54(\mathrm{CO}-\mathrm{O}) ; 162.92(\mathrm{C}=\mathrm{C}-\mathrm{OH})$; $176.70\left(\mathrm{H}_{3} \mathrm{C}-\mathrm{CO}\right)$. Elemental analysis \% calcd. (found) for $\mathrm{C}_{11} \mathrm{H}_{8} \mathrm{O}_{4}$ : C, 64.707 (64.60); H, 3.949 (4.09); N, 8.123 (8.07).

General procedure for the synthesis of 2-amino-6-(4hydroxy-2-oxo-chromen-3-yl)-4-(aryl) nicotine nitrile (4): A reaction mixture of $(5 \mathrm{mmol})$ of 3-acetyl-4-hydroxycoumarin, ( $5 \mathrm{mmol})$ of aromatic aldehyde, malonitrile $(5 \mathrm{mmol})$, with ammonium acetate $(10 \mathrm{mmol})$ and $10 \mathrm{~mL}$ of dichloromethane was refluxed for an appropriate time under continuous agitation. The reaction was followed by (TLC). After completion of the reaction, the mixture was cooled to room temperature. The solid obtained was filtered, washed with ice water and purified by recrystallization in $95 \%$ ethanol.

2-Amino-6-(4-hydroxy-2-oxo-chromen-3-yl)-4-phenyl nicotine nitrile (4a): Yield: $95 \%$; m.p.: $120^{\circ} \mathrm{C}$; FT-IR (KBr, $\left.v_{\max }, \mathrm{cm}^{-1}\right): 3505(\mathrm{O}-\mathrm{H}) ; 3402\left(\mathrm{NH}_{2}\right) ; 1592(\mathrm{C}=\mathrm{C}) ; 1715(\mathrm{CO}$ lactone), $2215(\mathrm{CN}) .{ }^{1} \mathrm{H}$ NMR (400 MHz, DMSO- $d_{6}$ ) in ppm: $\delta 7.27-8.18\left(\mathrm{~m}, 12 \mathrm{H}, 10 \mathrm{H}_{\text {arom }}+\right.$ aryl- $\left.\mathrm{NH}_{2}\right) .{ }^{13} \mathrm{C} \mathrm{NMR}(100 \mathrm{MHz}$, DMSO- $\left.d_{6}\right)$ in ppm: $\delta 104,125.7,124.6,123.5,122.4,112.9$, $119.1,153.5,152.1,143.3,134,128.7,128.4,127.5\left(C_{\text {arom }}\right)$; $116.2(\operatorname{aryl}-\mathrm{CN}) ; 108.8(\operatorname{aryl}-\mathrm{C}=\mathrm{C}-\mathrm{OH}) ; 136.6\left(\mathrm{O}-\mathrm{C}_{\text {arom }}\right) ; 159.5$ $(\mathrm{C}=\mathrm{C}-\mathrm{OH}) ; 157.9\left(\mathrm{NH}_{2}-\mathrm{C}_{\text {arom }}, \mathrm{O}-\mathrm{CO}_{\text {arom }}\right)$. Elemental analysis $\%$ calcd. (found) for $\mathrm{C}_{21} \mathrm{H}_{13} \mathrm{~N}_{3} \mathrm{O}_{3}: \mathrm{C}, 70.980$ (70.82); $\mathrm{H}, 3.687$ (3.90); N, 11.825 (11.80).

2-Amino-6-(4-hydroxy-2-oxo-chromen-3-yl)-4-(4methylphenyl)nicotine nitrile (4b): Yield: $75 \%$; m.p.: 142 ${ }^{\circ} \mathrm{C}$; FT-IR $\left(\mathrm{KBr}, v_{\max }, \mathrm{cm}^{-1}\right)$ : $3502(\mathrm{O}-\mathrm{H}) ; 3410\left(\mathrm{NH}_{2}\right) ; 1585$ $(\mathrm{C}=\mathrm{C}) ; 1710$ (CO lactone), $2215(\mathrm{CN}) .{ }^{1} \mathrm{H}$ NMR $(400 \mathrm{MHz}$, DMSO- $d_{6}$ ) in ppm: $\delta 2.27$ (s, 3H, aryl- $\left.\mathrm{CH}_{3}\right) ; 7.27-8.19(\mathrm{~m}$, $\left.11 \mathrm{H}, 9 \mathrm{H}_{\text {arom }}+\operatorname{aryl}-\mathrm{NH}_{2}\right) \cdot{ }^{13} \mathrm{C}$ NMR $\left(100 \mathrm{MHz}\right.$, DMSO- $\left.d_{6}\right)$ in ppm: $\delta 24.5$ (aryl- $\left.\mathrm{CH}_{3}\right) ; 104.1,125.7,124.6,123.5,116.2$, 153.6, 116.2, 104.1, 134.0, 132.8, 129.0, $127.4\left(\mathrm{C}_{\text {arom }}\right) ; 136.2$ $\left(\mathrm{O}-\mathrm{C}_{\text {arom }}\right) ; 119.1$ (aryl-CN); $112.9(\operatorname{aryl}-\mathrm{C}=\mathrm{C}-\mathrm{OH}) ; 157.9\left(\mathrm{NH}_{2^{-}}\right.$ $\left.\mathrm{C}_{\text {arom }}, \mathrm{O}-\mathrm{CO}_{\text {arom }}\right) ; 159.5(\mathrm{C}=\mathrm{C}-\mathrm{OH})$. Elemental analysis \% calcd. (found) for $\mathrm{C}_{22} \mathrm{H}_{15} \mathrm{~N}_{3} \mathrm{O}_{3}$ : C, 71.536 (71.60); H, 4.093 (3.09); $\mathrm{N}, 11.376$ (11.40).

2-Amino-6-(4-hydroxy-2-oxo-chromen-3-yl)-4-(4-N, $\mathrm{N}^{\prime}$ dimethylaminophenyl)nicotine nitrile (4c): Yield: $80 \%$; m.p.: $160^{\circ} \mathrm{C}$; FT-IR $\left(\mathrm{KBr}, v_{\max }, \mathrm{cm}^{-1}\right): 3441\left((\mathrm{O}-\mathrm{H}) ; \mathrm{NH}_{2}\right) ; 1604$ $(\mathrm{C}=\mathrm{C}) ; 1721$ (CO lactone), $2233(\mathrm{CN}) .{ }^{1} \mathrm{H}$ NMR $(400 \mathrm{MHz}$, DMSO- $\left.d_{6}\right)$ in ppm: $\delta 3.10\left(\mathrm{~s}, 6 \mathrm{H}\right.$, aryl- $\mathrm{N}\left(\mathrm{CH}_{32)}\right) ; 7.30(\mathrm{~s}, 2 \mathrm{H}$, aryl- $\left.\mathrm{NH}_{2}\right) ; 6.83-8.03\left(\mathrm{~m}, 9 \mathrm{H}, \mathrm{H}_{\text {arom }}\right) .{ }^{13} \mathrm{C}$ NMR $(100 \mathrm{MHz}$, DMSO- $\left.d_{6}\right)$ in ppm: $\delta 58.9,69.1\left(\operatorname{aryl}-\mathrm{N}\left(\mathrm{CH}_{3}\right)_{2}\right) ; 105.1,134.0$, $131.3,128.6,125.0,116.2,104.1,150.0,153.2,116.7,134.0$ $\left(\mathrm{C}_{\text {arom }}\right), 112.2($ aryl-C $=\mathrm{C}-\mathrm{OH}) ; 119.2(\operatorname{aryl}-\mathrm{CN}) ; 152.4(\mathrm{O}-$ $\left.\mathrm{C}_{\text {arom }}\right) ; 159.3(\mathrm{C}=\mathrm{C}-\mathrm{OH}) ; 158.3\left(\mathrm{O}-\mathrm{CO}_{\text {arom }}\right), 153.6\left(\mathrm{NH}_{2}-\mathrm{C}_{\text {arom }}\right)$.

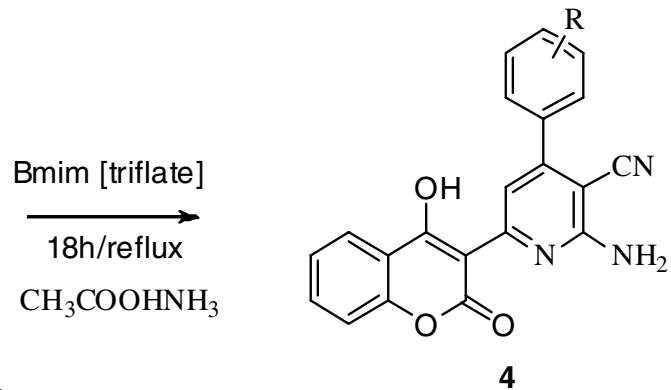

Scheme-I: Synthetic protocol of 2-amino-6-(4-hydroxy-2-oxo-chromen-3-yl) -4-aryl nicotine nitrile (4a-g) 
Elemental analysis \% calcd. (found) for $\mathrm{C}_{23} \mathrm{H}_{18} \mathrm{~N}_{4} \mathrm{O}_{3}: \mathrm{C}, 69.336$ (69.41); H, 4.554 (4.70); N, 14.062 (14.10).

2-Amino-6-(4-hydroxy-2-oxo-chromen-3-yl)-4-(4nitrophenyl)nicotine nitrile (4d): Yield: $85 \%$; m.p.: $210{ }^{\circ} \mathrm{C}$; FT-IR (KBr, $\left.v_{\max }, \mathrm{cm}^{-1}\right)$ : $3507(\mathrm{O}-\mathrm{H}) ; 3405\left(\mathrm{NH}_{2}\right) ; 1585(\mathrm{C}=$ C); 1715 (CO lactone), $2215(\mathrm{CN}) .{ }^{1} \mathrm{H}$ NMR $(400 \mathrm{MHz}$, DMSO- $\left.d_{6}\right)$ in ppm: $\delta 7.28\left(\mathrm{~s}, 2 \mathrm{H}\right.$, aryl- $\left.\mathrm{NH}_{2}\right) ; 7.62-8.40(\mathrm{~m}$, $\left.9 \mathrm{H}, \mathrm{H}_{\text {arom }}\right) .{ }^{13} \mathrm{C}$ NMR $\left(100 \mathrm{MHz}\right.$, DMSO- $\left.d_{6}\right)$ in ppm: $\delta 85.2$, 104.1, 134.0, 134.1, 125.6, 124.4, 148.8, 153.2, 143.4, 144.8, $130.1,125.6\left(\mathrm{C}_{\text {arom }}\right) 144.8\left(\mathrm{O}-\mathrm{C}_{\text {arom }}\right) ; 109.9(\mathrm{C}$ aryl-C $=\mathrm{C}-\mathrm{OH})$; 119.2 (aryl-CN); $177.9(\mathrm{C}=\mathrm{C}-\mathrm{OH}) ; 161.7\left(\mathrm{O}-\mathrm{CO}_{\text {arom }}\right), 153.6$ $\left(\mathrm{NH}_{2}-\mathrm{C}_{\text {arom }}\right.$ ). Elemental analysis \% calcd. (found) for $\mathrm{C}_{21} \mathrm{H}_{12} \mathrm{~N}_{4} \mathrm{O}_{5}$ : C, 63.002 (63.10); H, 3.021 (3.20); N, 13.995 (13.90).

2-Amino-6-(4-hydroxy-2-oxo-chromen-3-yl)-4-(3bromophenyl) nicotine nitrile (4e): Yield: $87 \%$; m.p.: 160 ${ }^{\circ} \mathrm{C}$; FT-IR $\left(\mathrm{KBr}, v_{\max }, \mathrm{cm}^{-1}\right)$ : $3502(\mathrm{O}-\mathrm{H}) ; 3405\left(\mathrm{NH}_{2}\right) ; 1592$ $(\mathrm{C}=\mathrm{C}) ; 1716$ (CO lactone), $2218(\mathrm{CN}) .{ }^{1} \mathrm{H}$ NMR $(400 \mathrm{MHz}$, DMSO- $\left.d_{6}\right)$ in ppm: $\delta 7.31-8.38\left(\mathrm{~m}, 11 \mathrm{H}, 9 \mathrm{H}_{\text {arom }}+\mathrm{NH}_{2}\right) \cdot{ }^{13} \mathrm{C}$ NMR (100 MHz, DMSO- $\left.d_{6}\right)$ in ppm: $\delta 100.9,134.0,134.1$, 125.6, 124.3, 148.8, 104.1, 132.9, 153.1, $125.7\left(\mathrm{C}_{\text {arom }}\right), 109.3$ (aryl-C=C-OH); 119.2 (aryl-CN); $139.3\left(\mathrm{O}-\mathrm{C}_{\text {arom }}\right) .159 .3(\mathrm{O}-$ $\left.\mathrm{CO}_{\text {arom }}\right), 178.4(\mathrm{C}=\mathrm{C}-\mathrm{OH}) ; 153.6\left(\mathrm{Br}-\mathrm{C}_{\text {arom }}\right) ; 154.0\left(\mathrm{NH}_{2}-\mathrm{C}_{\text {arom }}\right)$. Elemental analysis \% calcd. (found) for $\mathrm{C}_{21} \mathrm{H}_{12} \mathrm{~N}_{3} \mathrm{O}_{3} \mathrm{Br}$ : C, 58.084 (58.10); H, 2.785 (2.90); N, 9.677 (9.80).

2-Amino-6-(4-hydroxy-2-oxo-chromen-3-yl)-4-(3methoxyphenyl) nicotine nitrile (4f): Yield: $87 \%$; m.p.: 160 ${ }^{\circ} \mathrm{C}$; FT-IR $\left(\mathrm{KBr}, v_{\max }, \mathrm{cm}^{-1}\right)$ : $3510(\mathrm{O}-\mathrm{H}) ; 3437\left(\mathrm{NH}_{2}\right) ; 1604$ $(\mathrm{C}=\mathrm{C}) ; 1710$ (CO lactone), $2360(\mathrm{CN}) .{ }^{1} \mathrm{H}$ NMR $(400 \mathrm{MHz}$, DMSO- $\left.d_{6}\right)$ in ppm: $\delta 3.72\left(\mathrm{~s}, 3 \mathrm{H}\right.$, aryl- $\left.\mathrm{OCH}_{3}\right) ; 7.40(\mathrm{~s}, 2 \mathrm{H}$, aryl- $\left.\mathrm{NH}_{2}\right)$; 6.80-7.89 (m, 9H, $\left.\mathrm{H}_{\text {arom }}\right) .{ }^{13} \mathrm{C}$ NMR $(100 \mathrm{MHz}$, DMSO- $\left.d_{6}\right)$ in ppm: $\delta 55.4\left(\operatorname{aryl}-\mathrm{CH}_{3}\right) ; 112.4,133.3,130.1$, $125.1,122.9,120.1,119.6,125.7,117,97.9,145.3\left(C_{\text {arom }}\right)$; $97.9(\operatorname{aryl}-\mathrm{C}=\mathrm{C}-\mathrm{OH}) ; 104.3(\operatorname{aryl}-\mathrm{CN}) ; 160(\mathrm{C}=\mathrm{C}-\mathrm{OH}) ; 159.7$ $\left(\mathrm{O}-\mathrm{CO}_{\text {arom }}\right), 158.4\left(\mathrm{NH}_{2}-\mathrm{C}_{\text {arom }}\right) ; 153.9\left(\mathrm{O}-\mathrm{C}_{\text {arom }}\right) ; 152.6\left(\mathrm{H}_{3} \mathrm{C}-\right.$ $\mathrm{OC}_{\text {arom }}$ ). Elemental analysis \% calcd. (found) for $\mathrm{C}_{22} \mathrm{H}_{15} \mathrm{~N}_{3} \mathrm{O}_{4}$ : C, 68.566 (68.61); H, 3.923 (3.90); N 10.904 (10.82).

2-Amino-6-(4-hydroxy-2-oxo-chromen-3-yl)-4-(3hydroxyphenyl) nicotine nitrile (4g): Yield: $95 \%$; m.p.: 180 ${ }^{\circ} \mathrm{C}$; FT-IR (KBr, $\left.v_{\max }, \mathrm{cm}^{-1}\right)$ : $3501(\mathrm{O}-\mathrm{H})$; $3408\left(\mathrm{NH}_{2}\right) ; 1588$ $(\mathrm{C}=\mathrm{C}) ; 1731$ (CO lactone), $2233(\mathrm{CN}) .{ }^{1} \mathrm{H}$ NMR $(400 \mathrm{MHz}$, DMSO- $\left.d_{6}\right)$ in ppm: $\delta 7.02-8.51\left(\mathrm{~m}, 12 \mathrm{H}, 9 \mathrm{H}_{\text {arom }}+\operatorname{aryl}-\mathrm{NH}_{2}+\right.$ aryl-OH). ${ }^{13} \mathrm{C}$ NMR $\left(100 \mathrm{MHz}\right.$, DMSO- $\left.d_{6}\right)$ in ppm: $\delta 85.3$, $116.6,120.8,119.8,117.7,104.1,130.5,116.6,117.7\left(\mathrm{C}_{\text {arom }}\right)$; 92 (aryl-C=C-OH); $115.2(\operatorname{aryl}-\mathrm{CN}) ; 134.3\left(\mathrm{O}-\mathrm{C}_{\text {arom }}\right) ; 148.8$ $\left(\mathrm{NH}_{2}-\mathrm{C}_{\text {arom }}\right) ; 177.7(\mathrm{C}=\mathrm{C}-\mathrm{OH}) ; 158.0\left(\mathrm{O}-\mathrm{CO}_{\text {arom }}\right) ; 153.2(\mathrm{HO}-$ $\mathrm{C}_{\text {arom}}$ ). Elemental analysis \% calcd. (found) for $\mathrm{C}_{21} \mathrm{H}_{13} \mathrm{~N}_{3} \mathrm{O}_{4}$ : C, 67.922 (67.81); H, 3.53 (3.60); N 11.316 (11.42).

Biological analysis was performed according to previous study [19].

Bacterial strains, media and growth conditions: Bacteria strains used as indicator microorganisms for the antibacterial activity assays were: Micrococcus luteus LB14110, Staphylococcus aureus ATCC 6538, Listeria monocytogenes ATCC 19117 Salmonella typhimurium ATCC 14028 and Pseudomonas aeruginosa ATCC 49189 were obtained from international culture collections (ATCC) and local culture collection of the Laboratory of Microorganisms and Biomolecules of the Centre of Biotechnology of Sfax, Tunisia. These bacterial strains were grown overnight in Luria-Bertani (LB) agar medium $(\mathrm{g} / \mathrm{L})$ : peptone 10 ; yeast extract 5 and $\mathrm{NaCl} 5$ at $\mathrm{pH}$ 7.2 under aerobic conditions and constant agitation (200 rpm) at $30^{\circ} \mathrm{C}$ for M. luteus $\mathrm{LB} 14110$ and L. monocytogenes ATCC 19117 and at $37^{\circ} \mathrm{C}$ for $S$. aureus ATCC 6538, S. typhimurium ATCC 14028 and $P$. aeruginosa ATCC 49189 and then diluted 1:100 in LB media and incubated for $5 \mathrm{~h}$ under constant agitation $(200 \mathrm{rpm})$ at the appropriate temperature.

Agar well diffusion method: Agar well diffusion method was employed for the determination of the antimicrobials activity of the synthesized compounds according to Güven [20] with some modifications. Briefly, the synthesized compounds are allowed to diffuse out into the appropriate agar medium (LB agar medium) and interact in a plate freshly seeded with a suspension of the indicators microorganisms $\left(0.1 \mathrm{~mL}\right.$ of $10^{8}$ cells per $\left.\mathrm{mL}\right)$. The plate was incubated at the appropriate temperature after staying at $4{ }^{\circ} \mathrm{C}$ for $2 \mathrm{~h}$. The resulting zones of inhibition will be uniformly circular as there will be a confluent lawn of growth. The antibacterial activity was assayed by measuring in millimeters the diameter of the inhibition zone formed around the well. All tests are assayed in triplicate and expressed as the average \pm standard deviation of the measurements.

Minimum inhibitory concentration (MIC) were done regarding our previous study [19].

The minimum inhibitory concentration (MIC) of the synthesized compounds was determined in accordance with NCCLS guideline M7-A6 and M38-P [21]. The test was performed in sterile 96-well microplates with a final volume in each microplate well of $100 \mathrm{~mL}$. The synthesized compounds $(20 \mathrm{mg} / \mathrm{mL})$ were properly prepared in solution of dimethylsulfoxide/water (1/9; v/v). The inhibitory activity of each synthesized compound was transferred to each well in order to obtain a twofold serial dilution of the original sample and to produce the concentration range of $0.0048-20 \mathrm{mg} / \mathrm{mL}$. To each test well $10 \mathrm{~mL}$ of cell suspension were added to final inoculum concentrations of $10^{6} \mathrm{CFU} / \mathrm{mL}$ for each microorganisms. Positive growth control wells consisted of microorganisms only in their adequate medium. Cells suspension at the same concentration supplemented with ampicillin was used as control. The plates were then covered with the sterile plate covers and incubated at the appropriate temperature of each microorganism. The MIC was defined as the lowest concentration of the synthesized compound at which the microorganism does not demonstrate visible growth after incubation. As an indicator of microorganism growth, $25 \mathrm{~mL}$ of thiazolyl blue tetrazolium bromide (MTT), indicator solution $(0.5 \mathrm{mg} / \mathrm{mL})$ dissolved in sterile water were added to the wells and incubated at room temperature for $30 \mathrm{~min}$. This determination was done in triplicate and obtained results were very similar. The reported value is the average of the three tests.

Antioxidant activity: DPPH radical scavenging activity were done regarding our previous study [19].

Scavenging of 2,2-diphenyl-1-picrylhydrazyl radical (DPPH_assay) is the simplest and most widely reported method for screening antioxidant activity. The procedure involves measurement of decrease in absorbance of DPPH at its absorption maxima of $517 \mathrm{~nm}$. This assay determines the scavenging of 
stable radical species according to the method of Kirby and Schmidt [22] with slight modifications. Briefly, synthesized compounds were dissolved in dimethylsulfoxide (DMSO)/ water $(1 / 9 ; \mathrm{v} / \mathrm{v})$ and diluted with ultrapure water at different concentrations $(1,0.5,0.250,0.125,0.0625,0.03125 \mathrm{mg} / \mathrm{mL})$. Then, $500 \mathrm{~mL}$ of a $4 \%(\mathrm{w} / \mathrm{v})$ solution of DPPH radical in ethanol was mixed with $500 \mathrm{~mL}$ of samples. The mixture was incubated for $30 \mathrm{~min}$ in the dark at room temperature. The scavenging capacity was determined spectrophotometrically by monitoring the decrease in absorbance at $517 \mathrm{~nm}$ against a blank. The percentage of antiradical activity (\% ArA) had been calculated as follows:

$\operatorname{ArA}(\%)=\frac{\text { Absorbance of control }- \text { Absorbance of test sample }}{\text { Absorbance of control }} \times 100$

All tests are assayed in triplicate and expressed as the average \pm standard deviation of the measurements.

\section{RESULTS AND DISCUSSION}

The first efficient one-pot synthesis of 4-aryl-1,2-dihydro6-(4-hydroxy-2-oxo-2H-chromen-3-yl)-2-oxopyridin-3carbonitriles has been developed from malonitrile, aromatic aldehyde and 3-acetyl-4-hydroxy coumarin, the approach is outlined in Scheme-I.

3-Acetyl-4-hydroxycoumarin (1) was synthesized by acetylation of the 4-hydroxycoumarin, by the method of Dholakia et al. [23] using glacial acetic acid as acetylating agent in the presence of $\mathrm{POCl}_{3}$. The reaction was rapid, without involving any kind of competition from the intramolecular condensation of 4-hydroxycoumarin [24].

This compound 1 was characterized by $\mathrm{IR},{ }^{1} \mathrm{H}$ and ${ }^{13} \mathrm{C}$ NMR. The IR spectra of compound 1 revealed a strong band at $3185 \mathrm{~cm}^{-1}$ confirming the presence of $\mathrm{OH}$ group and showed band in the region of $1700 \mathrm{~cm}^{-1}$ which is the characteristic for $\mathrm{C}=\mathrm{O}$ of coumarin. The ${ }^{1} \mathrm{H}$ NMR shows that aromatic proton arrow as a multiplet between 7.15 and $7.92 \mathrm{ppm}$. A singlet at $2.45 \mathrm{ppm}$ was assigned to methylic proton whilst the $\mathrm{OH}$ signal appeared at $17.72 \mathrm{ppm}$. This very high value of the chemical shift might be explained by only an intermolecular hydrogen bond [25].

In order to seek optimal solvent and optimal amounts of catalyst, we run a model reaction by stirring equimolecular amounts of 3-acetyl-4-hydroxycoumarin (1) with malonitrile and benzaldehyde in the presence of ammonium acetate. The model reaction was explored using different solvents such as Bmim[triflate], DCM, DCE, ethanol, tetrahydrofuran and toluene in the presence of ammonium acetate. The results are summarized in Table-1.

It was found that polarity of solvent and the presence of ammonium acetate play an important role for the success of the reaction. The results indicated that solvents were also affected on the yield of of the products (Table-1). In the organic solvents such as dichloromethane, THF, ethanol, or toluene, the yield of $\mathbf{4}$ were lower and longer reaction times were required.

It was observed that among all solvents and media, the best result was obtained when Bmim[triflate] was chosen in the presence of ammonium acetate at $90{ }^{\circ} \mathrm{C}$. The desired product was obtained in excellent yield and high purity.
TABLE-1

SYNTHESIS OF 4-PHENYL-1,2-DIHYDRO-6-(4-HYDROXY-2OXO-2 $H$-CHROMEN-3-YL)-2-OXOPYRIDIN-3-CARBONITRILE (4a-g) IN THE PRESENCE OF DIFFERENT SOLVENTS

\begin{tabular}{ccccc}
\hline Entry & Solvent & Temp. $\left({ }^{\circ} \mathrm{C}\right)$ & Time $(\min )$ & Yield $(\%)^{\mathrm{a}}$ \\
\hline 1 & DCM & 90 & 30 & 83 \\
2 & DCE & 128 & 30 & 80 \\
3 & Ethanol & 78 & 120 & 72 \\
4 & THF & 66 & 120 & 62 \\
5 & Bmim [triflate] & 100 & 30 & 95 \\
6 & DCM & 40 & 120 & 60 \\
7 & Toluene & 110 & 120 & 62 \\
\hline
\end{tabular}

Reaction conditions: 3-acetyl-4-hydroxycoumarin (5 mmol), malonitrile $(5 \mathrm{mmol})$, benzaldehyde $(5 \mathrm{mmol})$, solvent $(15 \mathrm{~mL})$, reflux, ammonium acetate $(10 \mathrm{mmol})$.

${ }^{a}$ Isolated yield of product.

Also, in order to optimize the ammonium acetate loading, the model reaction was performed with different amounts of catalyst at ambient temperature. The results are summarized in Table-2.

TABLE-2

EFFECT OF CATALYST AMOUNT ON THE CONDENSATION OF BENZALDEHYDE, ETHYL CYANOACETATE AND 3ACETYL-4-HYDROXYCOUMARINE (1) IN Bmim[triflate] ${ }^{a}$

\begin{tabular}{ccccc}
\hline Entry & Catalyst & Mol (\%) & Time (h) & ${\text { Yield }(\%)^{\mathrm{b}}}^{\mathrm{b}}$ \\
\hline 1 & $\mathrm{NH}_{4} \mathrm{OAc}$ & 5 & 5 & 60 \\
2 & $\mathrm{NH}_{4} \mathrm{OAc}$ & 10 & 10 & 85 \\
3 & $\mathrm{NH}_{4} \mathrm{OAc}$ & 15 & 3 & 82 \\
4 & $\mathrm{NH}_{4} \mathrm{OAc}$ & 20 & 3 & 95 \\
5 & $\mathrm{NH}_{4} \mathrm{OAc}$ & 25 & 3 & 92 \\
6 & $\mathrm{NH}_{4} \mathrm{OAc}$ & 30 & $10 \mathrm{~h} 20 \mathrm{~min}$ & 88 \\
7 & No catalyst & - & $10 \mathrm{~h} 20$ min & 10 \\
\hline \\
'Reaction & conditions: & 3 -acetyl-4-hydroxycoumarin & $(5$ & mmol), \\
malonitrile (5 mmol), benzaldehyde (5 mmol), solvent $(15 \mathrm{~mL})$, reflux. \\
'Isolated yield of product.
\end{tabular}

It was found that, when the reaction was carried out in the presence of $5 \mathrm{~mol} \%$ of catalyst, $60 \%$ of yield was obtained. As we increase the percentage of the catalyst to 10,15 and 20 mol \%, the yields were also found to be increased up to 85 , 82 and $95 \%$, respectively, but beyond $20 \mathrm{~mol} \%$ there is no significant improvement of the rate as well as yield of the reaction and further increase in the quantity of catalyst did not show appreciable improvement in the yield of product. Thus, $20 \mathrm{~mol} \%$ of catalyst was chosen as maximum quantity of the catalyst for the reaction.

To explore the scope and generality of this multicomponent reaction (MCR), we tried to construct a library of 2-amino-6-(4-hydroxy-2-oxo-chromen-3-yl)-4-aryl nicotine nitrile (4a-g) derivatives using the optimized reaction conditions, the scope of the method was investigated with a series of substituted aromatic aldehydes (Scheme-I).

A variety of aryl aldehydes containing different substituents (e.g. $-\mathrm{NO}_{2},-\mathrm{OH},-\mathrm{Br},-\mathrm{OCH}_{3},-\mathrm{OMe},-p-\mathrm{N}\left(\mathrm{CH}_{3}\right)_{2}$ reacted in this MCR to provide excellent product yields (75$95 \%)$. The aromatic aldehydes carrying both electron withdrawing (Entries 1-5) and electron-donating functional groups under-went successful condensation with ethyl cyanoacetate and 4-hydroxycoumarin in the presence of catalytic amount of ammonium acetate in Bmim[triflate] at reflux to afford the 
corresponding products $\mathbf{4 a - g}$ in good yields. moreover, the electronic effects of the substituent were not observed.

In IR spectra, bands in the region $3510-3414 \mathrm{~cm}^{-1}$ were attributed to the $\mathrm{OH}$ group of $\mathbf{4 a - g}$ seriesand bands in the region $1625-1520 \mathrm{~cm}^{-1}$ were attributed to symmetric and asymmetric frequency of the $\mathrm{NO}_{2}$ group of the compound 4d. Bands at $1731-1710 \mathrm{~cm}^{-1}$ obtained from the lactone ring of coumarin CO. $1585-1604 \mathrm{~cm}^{-1}$ stretching frequencies correspond to the $\mathrm{C}=\mathrm{C}$ groups of coumarins derivatives. In ${ }^{1} \mathrm{HNMR}$ spectra, the singlet between $\delta 7.27-7.40 \mathrm{ppm}$ corresponds to the presence of the $\mathrm{NH}_{2}$ group of the compounds $\mathbf{4 a - g}$. The absence of methylic proton signal at $\delta=2.45 \mathrm{ppm}$ and the presence of the signal of $\mathrm{NH}_{2}$ at support the formation of compounds 4ag. In ${ }^{13} \mathrm{C}$ NMR, signal at $\delta 119.2$ assigned to $\mathrm{CN}$, signal at $\delta$ 168.2-169.2 confirmed lactone carbonyl of $\mathbf{4 c}$ and the signal at $\delta 3.10$ ppm due to $\mathrm{N}\left(\underline{\mathrm{CH}}_{3}\right)_{2}$. Other signals are in good agreement with the target compounds in accordance with the literature data for other 4-hydroxycoumarin derivatives [26-33].

The formation of compound $\mathbf{4}$ could be explained by the reaction sequence in Scheme-II. First, condensation of<smiles>CC(=O)O[C@@H]1C=CC=C1C#N</smiles>

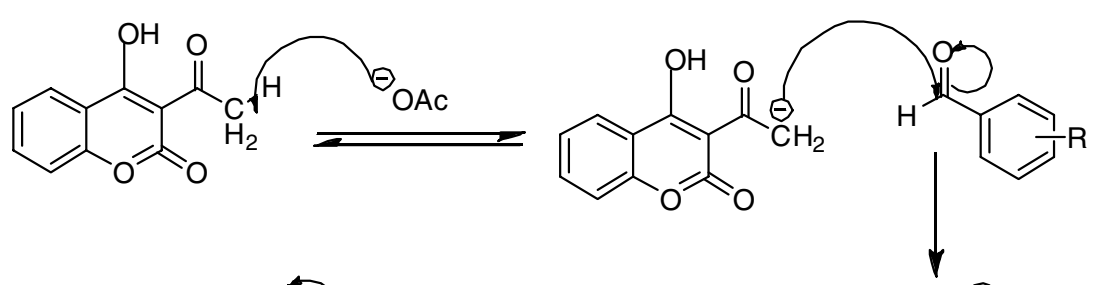<smiles>[R][R]1ccc(C([O-])CC(=O)c2c(O)c3ccccc3oc2=O)cc1</smiles><smiles>N#CC(C#N)COc1ccc(C(=O)C=Cc2c(O)c3ccccc3oc2=O)cc1</smiles>

$\left(i_{1}\right)$<smiles>N#CC(C#N)C(/C=C(\O)c1c(O)c2ccccc2oc1=O)c1ccc(I)cc1</smiles>

$\left(\mathrm{i}_{2}\right)$

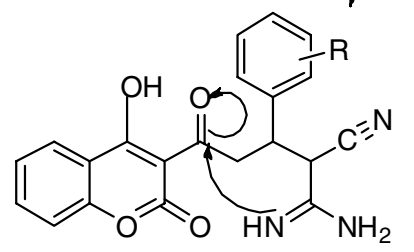

$\left(\mathrm{i}_{3}\right)$<smiles>[R]c1ccc(C2CC(O)(c3c(O)c4ccccc4oc3=O)NC(N)=C2C#N)cc1</smiles>

Scheme-II: A proposed mechanism for the three-component synthesis of 4-aryl-1,2-dihydro-6-(4-hydroxy-2-oxo-2H-chromen-3-yl)-2oxopyridin-3-carbonitriles (4a-g) 
3-acetyl-4-hydroxycoumarin (1) with arylaldehydes is proposed to give intermediate $\left(i_{1}\right)$, then malonitrile react with intermediate $\left(i_{1}\right)$ to give intermediate $\left(i_{2}\right)$ occurs to provide the intermediate $\left(i_{3}\right)$ which undergoes isomerization to form the target 4-aryl-1,2-dihydro-6-(4-hydroxy-2-oxo-2H-chromen-3yl)-2-oxopyridin-3-carbonitriles (4a-g).

In second path, we tried to synthetize coumarins derivatives 4 with another route. The 3-acetyl-4-hydroxycoumarin (1) condensed with arylaldehydsin the presence of piperidine gaves intermediate (i), then this precursor was refluxed with malonitrile and Bmim[triflate] to achieve targeted molecule $\mathbf{4}$ (Scheme-III).

The molecular structures and purity of the newly synthesized compounds were identified by NMR $\left({ }^{1} \mathrm{H}\right.$ and $\left.{ }^{13} \mathrm{C}\right)$, FTIR and elemental analysis (CHN). In FT-IR spectra, absorption bands attributed to symmetric and asymmetric stretching vibrations of amino groups appeared within $v=3456-3428$ and $3326-3281 \mathrm{~cm}^{-1}$, as well as stretching vibrations of nitro groups were recorded within $v=1543-1514$ and $1331-1318 \mathrm{~cm}^{-1}$. The presence of nitrile groups was deduced both from IR bonds at $\mathrm{V}=2228-2206 \mathrm{~cm}^{-1}$.

In summary, both synthetic routes successfully provided a strategy for synthesis of synthesized 2-amino-6-(4-hydroxy2-oxo-chromen-3-yl)-4-(aryl) nicotinenitrile 4a-g.

In first route, the 2-amino-6-(4-hydroxy-2-oxo-chromen3-yl)-4-(aryl) nicotine nitrile 4a-g is available and the starting material is low-cost and can be obtained easily. This synthetic route not only saves the time but lowers the cost for manufacture. The second route is longer. For these reasons, it is not suitable for large scale preparation. The second route is based on the materials commercially available, the reaction involves 2 steps. The total yield was up to $20 \%$.

Antioxidant activity of synthesized 2-amino-6-(4hydroxy-2-oxo-chromen-3-yl)-4-(aryl)nicotinenitrile (4a-g): The in vitro antioxidant activities of the coumarins derivatives 4 were screened using the DPPH (1,1-diphenyl-2picrilhydrazyl). The results obtained from the two approaches were consistent

L-Ascorbic acid and BHT were used as the standard antioxidant. The results are expressed as $\mathrm{mg} / \mathrm{mL}$ The activity results of the newly synthesized compounds are represented in Fig. 1. We found that most of the compounds showed considerable free radical scavenging activity.

The analysis of the results shows that the profiles of antiradical activity obtained reveal that most of the synthetic products tested have an antiradical activity. The three products $\mathbf{4 a}, \mathbf{4 d}$ and $\mathbf{4 e}$ have a medium antioxidant activity, while the product $\mathbf{4 f}$ has a very significant activity and close to the antiradical activity of the two synthetic antioxidants used as references (gallic acid and BHT).

Antimicrobial activity of 2-amino-6-(4-hydroxy-2-oxochromen-3-yl)-4-(aryl) nicotine nitrile (4a-g): The in vitro antibacterial activity of the samples $\mathbf{4 a - g}$ was assessed against Escherichia coli, Staphylococcus aureus, Pseudomonas aeruginosa, Salmonella typhimurium, Listeria monocytogenes, Micrococcus luteus and Candida albicans, respectively. The different bacterial species used Gram-positive bacteria: Micrococcus luteus LB14110, Staphylococcus aureus ATCC 6538, Listeria monocytogenes ATCC 19117, Gram-negative bacteria: Escherichia coli, Salmonella typhimurium ATCC

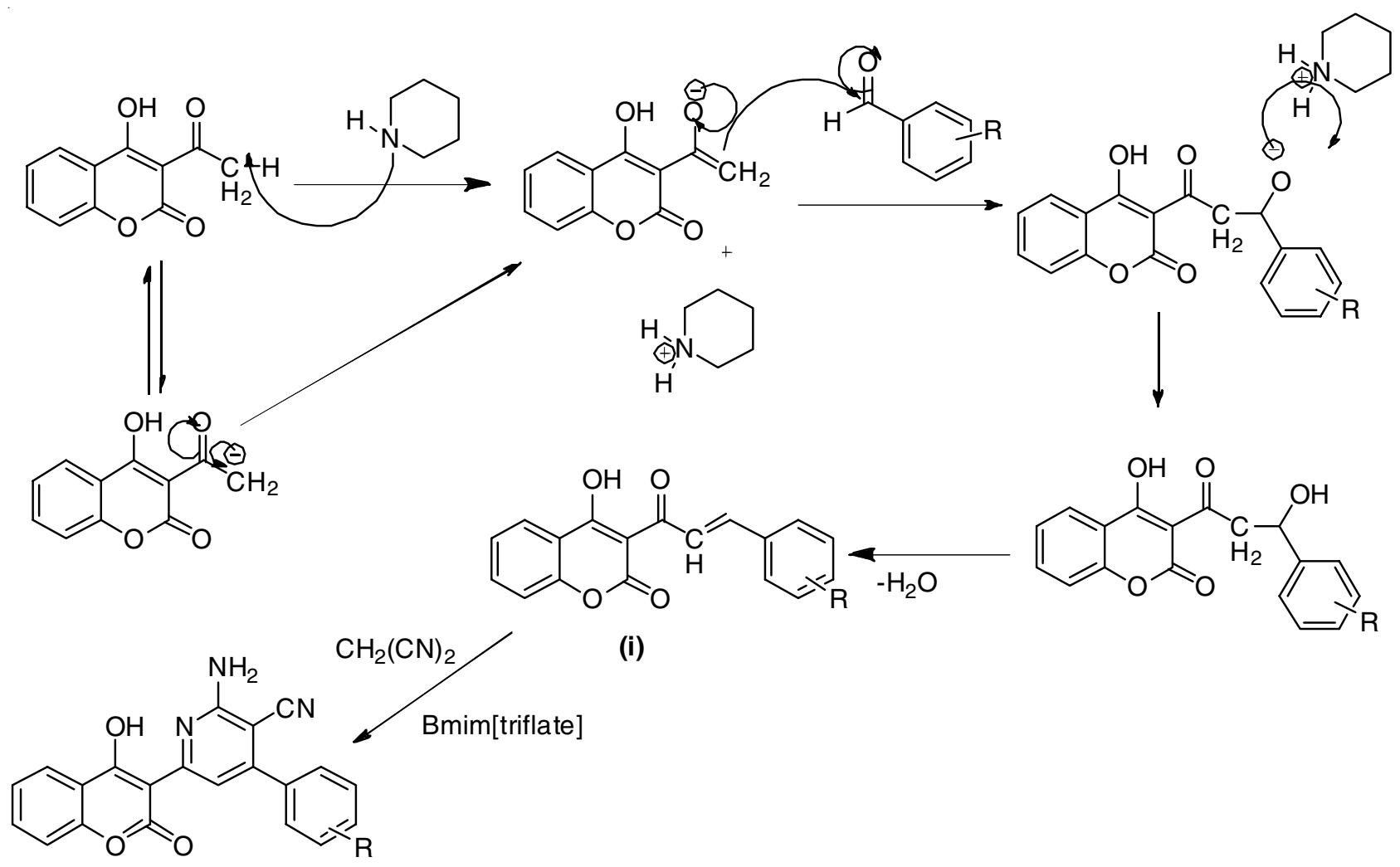



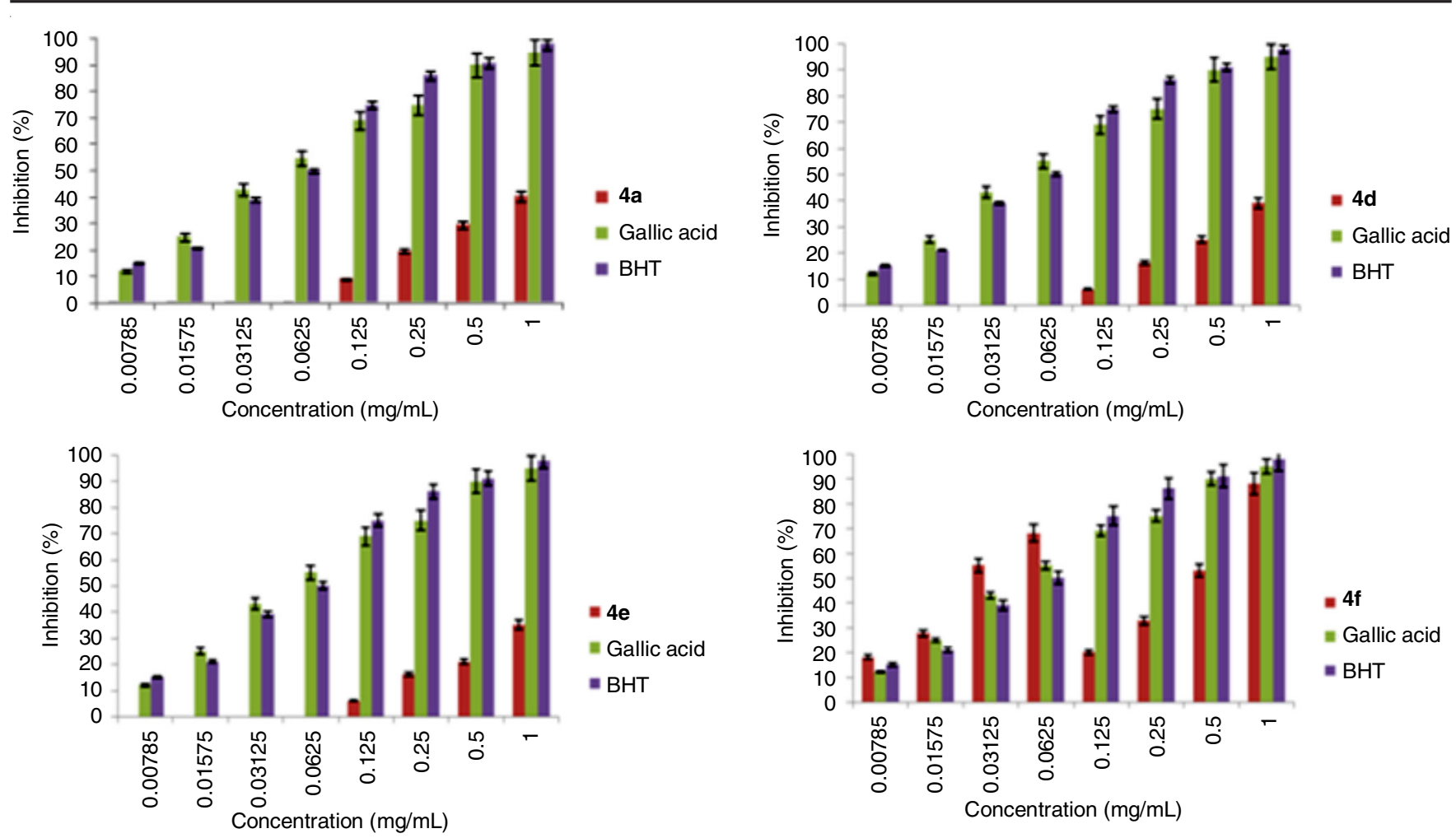

Fig. 1. Scavenging activity of 2-amino-6-(4-hydroxy-2-oxo-chromen-3-yl)-4-(aryl)nicotine nitrile (4) on DPPH radical

14028 and Pseudomonas aeruginosa and the fungus Candida albicans were provided by the Laboratory of Microorganisms and Biomolecules of the Biotechnology Center of Sfax. These species kept on nutrient agar, are reactivated on agar medium $24 \mathrm{~h}$ before performing the antimicrobial tests.

As a first approach, we used the traditional method of detecting antimicrobial activities (well method). The synthesized products are prepared with DMSO at an initial concentration of $20 \mathrm{mg} / \mathrm{mL}$. All the results of this study are shown in Fig. 2.

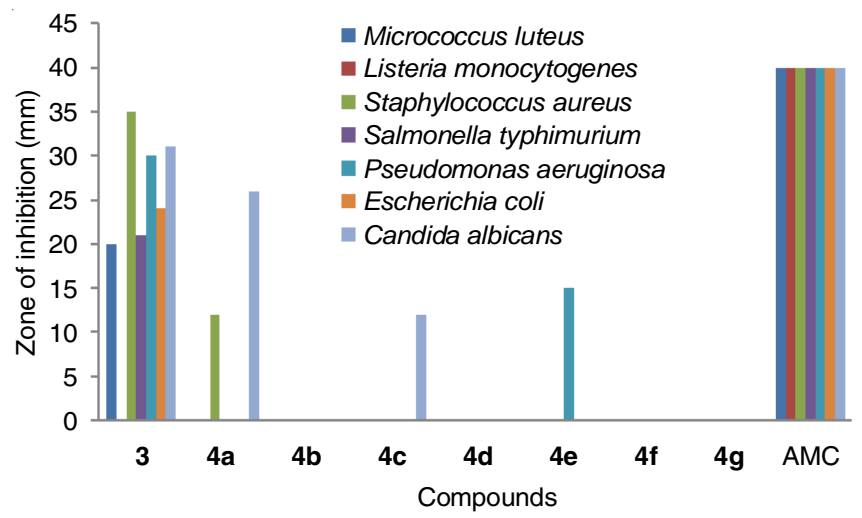

Fig. 2. Antibacterial activity of the prepared compounds $4 \mathbf{4 a - g}$

It is found that the activity of the synthesized compounds depends on their concentration and the bacterial strain tested. Gram-positive bacteria were more sensitive to the antimicrobial properties of synthesized compounds than Gram-negative bacteria. This effect can be attributed to the great complexity of the membrane-containing cell envelope in Gram-negative bacteria compared to the unique structure of Gram-positive membrane.

From Fig. 2, compound 4a was effective against Candida albicans and against Staphylococcus aureus ATCC 6538, this compound has moderate activity. However, compound $4 \mathbf{e}$ synthesized and tested in this study shows significant activity against Pseudomonas aeruginosa ATCC 49189.

Determination of minimum inhibitory concentration (MIC): Minimum inhibitory concentration (MIC) values were determined using the standard broth micro-dilution technique recommended by the Clinical and Laboratory Standard Institute $[34,35]$. The MIC results showed that all tested coumarin peptide salts (Table-3) had weak antimicrobial effects against E. coli and good to moderate effects against $S$. aureus.

\begin{tabular}{lcccc}
\multicolumn{5}{c}{ TABLE-3 } \\
MIC VALUES OF PRODUCTS TESTED \\
AGAINST TWO BACTERIA AND ONE FUNGUS \\
\hline Microorganisms & $\mathbf{3}$ & $\mathbf{4 a}$ & Ampicilline & Fluconazole \\
\hline S. aureus & 0.6250 & 1.2500 & 0.04 & - \\
P. aeruginosa & 0.3125 & 1.2500 & 0.04 & - \\
C. albicans & 0,1562 & 0.0195 & - & 0.00125 \\
\hline
\end{tabular}

According to the data reported in Table-3, the derivatives were ordered based on the spread of inhibitory properties and the MIC values as follows:

$$
4 b>4 e>4 d>4 c
$$

We evaluated the antimicrobial activity of the two synthetic products $\mathbf{3}$ and $\mathbf{4 a}$ with the highest activity against two bacteria ( $S$. aureus and $P$. aeruginosa) and against a fungus (Candida albicans) by the determination of the MIC in a liquid 
medium. For $S$. aureus ATCC 6538: 0.625 and $1.25 \mu \mathrm{g} / \mathrm{mL}$ respectively for products $\mathbf{3}$ and $\mathbf{4 a}$ and for $P$. aeruginosa ATCC 49189: 0.3125 and $1.25 \mu \mathrm{g} / \mathrm{mL}$, respectively for products 3 and $4 \mathbf{a}$.

\section{Conclusion}

In conclusion, a series of 2-amino-6-(4-hydroxy-2-oxochromen-3-yl)-4-(aryl) nicotine nitrile were designed, synthesized using two routes and evaluated for their antimicrobial and antioxidant activities. The obvious advantages of the methods are: operational simplicity, high atom economy and excellent yields. The preparations of the new products are supported by elemental analyses, IR and ${ }^{1} \mathrm{H}$ NMR and ${ }^{13} \mathrm{C}$ NMR. The compounds 4a-g were investigated for antioxidant activities by DPPH (2,2-diphenyl-1-picrylhydrazyl). Furthermore, compounds 4a-g were evaluated for antimicrobial activity by well method and determination of minimum inhibitory concentration (MIC). These compounds may serve as lead compounds for further development into novel antimicrobial and antioxidant agents. In addition the obtained compounds $\mathbf{4}$ we be used as new materials for hydrogen storage.

\section{ACKNOWLEDGEMENTS}

The authors gratefully acknowledge Qassim University represented by the Deanship of Scientific Research on the material support for this research under the number 5272alrasscac-2018-1-14-S during the academic year 1440AH/ 2018AD

\section{CONFLICT OF INTEREST}

The authors declare that there is no conflict of interests regarding the publication of this article.

\section{REFERENCES}

1. M.A. Musa, V.L. Badisa, L.M. Latinwo, J. Cooperwood, A. Sinclair and A. Abdullah, Anticancer Res., 31, 2017 (2011).

2. P. Borah, P. Seetham Naidu and P.J. Bhuyan, Tetrahedron Lett., 53, 5034 (2012);

https://doi.org/10.1016/j.tetlet.2012.07.060.

3. S.L. El-Ansary, S.E. Abbas, A.N. Mikhael and H.A. El-Banna, Egypt. J. Pharm. Sci., 33, 639 (1992).

4. S. Manfredini, D. Simoni, R. Ferroni, R. Bazzanini, S. Vertuani, S. Hatse, J. Balzarini and E. De Clercq, J. Med. Chem., 40, 3851 (1997); https://doi.org/10.1021/jm9602322.

5. L.W. Wattenberg, K.T. Lam and A.V. Fladmoe, Cancer Res., 39, 1651 (1979).

6. Y. Kashman, K.R. Gustafson, R.W. Fuller, J.H. Cardellina, J.B. McMahon, M.J. Currens, R.W. Buckheit, S.H. Hughes, G.M. Cragg and M.R. Boyd, J. Med. Chem., 35, 2735 (1992); https://doi.org/10.1021/jm00093a004.

7. T.C. Mckee, R.W. Fuller, C.D. Covington, J.H. Cardellina, B.L. Krepps, R.J. Gulakowski, J.B. McMahon and M.R. Boyd, J. Nat. Prod., 59, 754 (1996); https://doi.org/10.1021/np9603784.

8. N.F. Anjum, A. Aleem, N. Nayeem and S.M. Asdaq, Der Pharm. Chem., 3, 56 (2011).

9. S.M. De Souza, F. Delle Monache and A. Smânia Jr., Z. Naturforsch. C, 60, 693 (2005); https://doi.org/10.1515/znc-2005-9-1006.
10. A. Behrami, Orient. J. Chem., 30, 1747 (2014); https://doi.org/10.13005/ojc/300433.

11. J. Jung, J. Kim and O. Park, Synth. Commun., 29, 3587 (1999); https://doi.org/10.1080/00397919908085993.

12. W.M. Barker, M.A. Hermodson and K.P. Link, J. Med. Chem., 14, 167 (1971); https://doi.org/10.1021/jm00284a022.

13. M. Greaves, PLoS Med., 2, 342 (2005); https://doi.org/10.1371/journal.pmed.0020342.

14. C. Montagner, S.M. de Souza, C. Groposo, F. Delle Monache, E.F.A. Smânia and A. Smânia Jr., Z. Naturforsch. C, 63, 21 (2008); https://doi.org/10.1515/znc-2008-1-205.

15. R. de Araújo, F. Guerra, E. de O. Lima, C. de Simone, J. Tavares, L. Scotti, M. Scotti, T. de Aquino, R. de Moura, F. Mendonça and J. BarbosaFilho, Int. J. Mol. Sci., 14, 1293 (2013); https://doi.org/10.3390/ijms14011293.

16. G. Mazzone, N. Malaj, A. Galano, N. Russo and M. Toscano, RSC Adv., 5, 565 (2015); https://doi.org/10.1039/C4RA11733F

17. J. Raboin, M. Beley and G. Kirsch, Tetrahedron Lett., 41, 1175 (2000); https://doi.org/10.1016/S0040-4039(99)02255-8.

18. N.B. Karatzas, Hellenic J. Cardiol., 55, 89 (2014).

19. N. Touj, A. Chakchouk-Mtibaa, L. Mansour, A.H. Harrath, J.H. Al-Tamimi, I. Özdemir, L. Mellouli, S. Yasar and N. Hamdi, J. Organomet. Chem., 853, 49 (2017); https://doi.org/10.1016/j.jorganchem.2017.09.024.

20. K. Güven, E. Yücel and F. Cetintas, Pharm. Biol., 44, 79 (2006); https://doi.org/10.1080/13880200600591253.

21. National Committee for Clinical Laboratory Standard, Referece method for Broth Dilution Antifungal Susceptibility Testing of ConidiumForming Filamentous Fungi, Proposed Standard M38-P; National Committee for Clinical Laboratory Standard: Wayne, USA (1998)

22. A.J. Kirby and R. Schmidt, J. Ethnopharmacol., 56, 103 (1997); https://doi.org/10.1016/S0378-8741(97)01510-9.

23. V.N. Dholakia, M.G. Parekh and N.K. Trivedi, Aust. J. Chem., 21, 2345 (1968); https://doi.org/10.1071/CH9682345.

24. M. Eggenweiler, M. Gassen, J. Rochus, O. Poeschke and M. Wolf, Chem. Abstr., 134, 331 (2001).

25. K.C. Fylaktakidou, D.J. Hadjipavlou-Litina, K.E. Litinas and D.N. Nicolaides, Curr. Pharm., 10, 3813 (2004); https://doi.org/10.2174/1381612043382710.

26. F. Moreau, N. Desroy, J.M. Genevard, V. Vongsouthi, V. Gerusz, G. Le Fralliec, C. Oliveira, S. Floquet, A. Denis, S. Escaich, K. Wolf, M. Busemann and A. Aschenbrenner, Med. Chem. Lett., 18, 4022 (2008); https://doi.org/10.1016/j.bmcl.2008.05.117.

27. A. Dömling, Chem. Rev., 106, 17 (2006); https://doi.org/10.1021/cr0505728.

28. J.J. Wang, X. Feng, Z. Xun, D.Q. Shi and Z.B. Huang, J. Org. Chem., 80, 8435 (2015) https://doi.org/10.1021/acs.joc.5b01314.

29. A. Kumar, M.K. Gupta and M. Kumar, Tetrahedron Lett., 52, 4521 (2011); https://doi.org/10.1016/i.tetlet.2011.06.040.

30. P.P. Ghosh and A.R. Das, Tetrahedron Lett., 53, 3140 (2012); https://doi.org/10.1016/j.tetlet.2012.04.033.

31. H.Y. Wang, X.C. Liu, X. Feng, Z.B. Huang and D.Q. Shi, Green Chem., 15, 3307 (2013); https://doi.org/10.1039/c3gc41799a.

32. S. Khodabakhshi and B. Karami, Tetrahedron Lett., 55, 7136 (2014); https://doi.org/10.1016/j.tetlet.2014.11.016.

33. S. Yaragorla, A. Pareek and R. Dada, Tetrahedron Lett., 56, 4770 (2015); https://doi.org/10.1016/i.tetlet.2015.06.049.

34. A. Braca, N. De Tommasi, L. Di Bari, C. Pizza, M. Politi and I. Morelli, J. Nat. Prod., 64, 892 (2001); https://doi.org/10.1021/np0100845.

35. J.C. Cappuccino and N. Sherman, Microbiology-A Laboratory Manual, Addison Wesley: California, USA, p. 263 (1999). 